\title{
Summaries and abstracts
}

Yellow Book 2011 - I dati sul servizio di distribuzione e vendita del gas naturale in Italia, di Lorenzo Bardelli

L'articolo è tratto dello studio elaborato dal centro studi Utilitatis "Yellow Book I dati sul servizio di distribuzione del gas naturale in Italia". La pubblicazione affronta il tema della regolazione della distribuzione del gas naturale in Italia, partendo dalla descrizione degli attuali - e futuri - assetti istituzionali (modelli di governance e forme di gestione degli operatori), cui segue una approfondita analisi delle tariffe applicate all'utenza e la corrispondente spesa delle famiglie. L'articolo passa, poi, ad esaminare le grandezze economiche e patrimoniali riportate nei bilanci dei principali distributori nazionali, aggregati per classi dimensionali. Nella terza parte del lavoro si affronta il tema delle gare per l'affidamento del servizio, offrendo una visione critica dei criteri di selezione scelti dagli enti affidanti e degli esiti delle procedure stesse.

Parole chiave: gas, distribuzione, regolamentazione, gare, concessioni.

\section{Yellow Book 2011 - Gas distribution and retail in Italy, by Lorenzo Bardelli}

The article consists of an extract of the work prepared by the study center Utilitatis, "Yellow Book - I dati sul servizio di distribuzione del gas naturale in Italia". The publication addresses the issue of the regulation of natural gas distribution in Italy, starting from a description of the current - and future - institutional structures (governance models and management forms of the operators), followed by a thorough analysis of the fees charged to users, and the corresponding household expenditure. The article goes, then, to examine the economic and financial variables derived from the balance sheets of major national distributors, aggregated by dimensional clusters. The third part of the work addresses the issue of tenders for the service concession, offering a critical view of the selection criteria chosen by the contracting bodies and the outcomes of the procedures.

Keywords: gas, distribution, regulation, tenders, concessions.

JEL classifications: L5, L95, L98.

Economia delle fonti di energia e dell'ambiente n. 3, 2010 
Il settore elettrico UK e la riforma per far coesistere generazione pulita e meccanismi di mercato, di Stefano Verde

Proprio nel mercato elettrico più liberalizzato d'Europa si riflette sulla coesistenza tra de-carbonizzazione e regole di mercato, al fine di rispettare gli ambiziosi obiettivi europei di politica energetica. Questo lavoro ripercorre le recenti proposte di riforma avanzate dal governo britannico, confrontandole con quelle con cui il regolatore inglese aveva avviato un anno prima l'attuale dibattito sul market design del settore elettrico d'oltremanica.

Parole chiave: decarbonizzazione, elettricità, disegno del mercato, politica energetica, Regno Unito, riforma.

Uk electricity market reform: How to make clean generation and market mechanisms coexistent, by Stefano Verde

The EU most liberalized electricity market is thinking on the coexistence of decarbonisation and market functioning, in order to fulfil the ambitious European energy policy targets. This paper provides a review of the recent reform proposal put forward by the British Government and compares it with the 1-year older Ofgem's document that launched the current debate on UK power market design.

Keywords: decarbonization, electricity, market design, energy policy, reform, United Kingdom.

JEL classifications: L94, L98-L50.

Dati ufficiali, ufficiosi, prevedibili sulle biomasse ad uso energetico in Italia a fine 2010 e sulla copertura degli impegni al 2020, di Giuseppe Tomassetti

L'Italia è impegnata per il 2020 a contribuire a coprire i suoi usi finali di energia con almeno 20 Mtep ottenuti da fonti rinnovabili. L'attenzione si è finora concentrata sulle fonti più conosciute e non si è data attenzione alle attività non formalizzate così per il 2010 si è individuata una fornitura di 10,7 Mtep di fonti rinnovabili, di cui circa 4 Mtep di origine idro non più espandibile. Questo ritardo ha motivato incentivi molto rilevanti per i produttori da alcune fonti rinnovabili, incentivi peraltro poco efficaci sia per la modestia dei risultati sia per le limitate ricadute sulle manifatture nazionali.

Varie indagini sul campo indicavano l'esistenza di rilevanti consumi non formalizzati di biomasse, una stima prudente delle quantità porta a valutare un ulteriore contributo di almeno 5 Mtep, arrivando così per il 2010 ad un contributo di 16,78 Mtep, il $75 \%$ dell'obiettivo da raggiungere. Francia e Germania hanno già formalizzato questo riconoscimento, aggiungendo 7/8 Mtep ai loro consuntivi storici.

Queste considerazioni indicano che da una parte l'Italia deve potenziare con urgenza il suo sistema di statistiche sull'energia, dall'altra che c'e il tempo per riesaminare la struttura degli incentivi senza l'obbligo di cercare ogni contributo senza attenzione ai costi.

Parole chiave: biomasse, statisctiche energetiche, Italia. 
Official and real data on biomass energy use in Italy in 2010 and its role in the achievement of the 2020 RES supply target, by Giuseppe Tomassetti

Italy is committed to supply about 20 Mtoe from renewable energy sources (RES) by 2020 . The attention so far has been focused on RES that are included in the national energy balance (NEB) whereas other RES have been neglected because they are not included in the official statistics. For example, according to the Italian NEB in 2010 the RES supplied 10.7 Mtoe, of which about 4 Mtoe of hydroelectricity . Consequently Italy seems far away from achieving its target. This gap gave rise to very substantial incentives allotted to some RES production, even if they are quite inefficient for both the modesty of the results and the limited impact on domestic manufacturers.

Several field investigations indicate a significant amount of biomass consumption not accounted for in Italy. A conservative estimate of the biomass used in the final consumption is at least 5 Mtoe, bringing the total amount of RES contribution to 16.78 Mtoe in 2010. France and Germany have already formalized this recognition, and added 7-8 Mtoe to their historical energy consumption data.

These considerations indicate that on one hand Italy urgently needs to improve its system of energy statistics and on the other hand that it is time to review the incentive structure without an obligation to seek any contribution without attention to costs.

Keywords: biomass, energy staristics, Italy.. JEL classifications: Q23, Q16, Q40.

L'Italia e il nuovo nucleare: un'intricata questione di norme, regole e sentenze, di Antonio Di Martino, Antonio Sileo

Il programma nazionale per il ritorno all'energia nucleare, delineato da un' articolata normativa, è stato da subito osteggiato dalle Regioni. Dopo una prima e importante vittoria dello Stato (pronuncia favorevole della Consulta), si è registrato un buon punto a favore degli enti locali: nuova sentenza della Corte costituzionale.

La partita è ancora aperta, e mentre diversi ritardi si sono già accumulati, pare certo il ricorso a un nuovo referendum.

Italy and the nuclear renaissance: A tangle of laws, rules and court decisions, by Antonio Di Martino, Antonio Sileo

Since the beginning, the National Plan for starting over nuclear production, outlined in a complicated set of laws, has been opposed by local governments. On the subject the Italian Constitutional Court has already ruled twice: one in favour of and one against the national government. The issue is not yet settled and the referendum that has been scheduled on the topic might delay (or halt) the nuclear program.

Keywords: italian nuclear program, energy policy, local governments, Constitutional Court.

JEL classifications: Q58, K20. 
Wind power industry in Italy: State and competitiveness factors. An adjusted diamond model approach, by Marco Frey, Roberta Squillace

Wind energy has grown significantly in the recent years worldwide, as an option in achieving sustainability in the energy sector. In Italy the wind capacity installed has boomed as well, in terms of capacity installed and government incentives given to the sector, achieving the record value od 5,797 MW installed in 2010, positioning itself 6th below countries as China, US, Germany, Spain and India. As a new developing sector, the present paper aims to investigate which are the features of the new emerging industry and which factors are affecting its competitiveness. Moreover, some findings have been used to identify and discuss which are the main weakness and strengths, threats and opportunities of the sector. In order to have an integrated picture of the industry competitiveness, they have been used those categories belonging to the theoretical framework of Porter's Diamond Model, namely (1) Factor Conditions, (2) Demand Conditions, and (3) Firm's Strategy, Structure and Rivalry, (4) Related and Support Industry, (5) Government and (6) Chance. The model has been adjusted taking into account some critics and improvements of the original Porter model.

Each category has been analysed in details; data that comes from archival documents were reviewed carefully in order to select the more authoritative sources. A crucial part of the study concerns the analysis of technology capability and the firm's strategy and rivalry and the support industry; arguments have been deepen by using a survey that has involved companies operating along the wind supply chain in Italy. The survey offered the opportunity to have a "firm's perspective", concerning the perceptions of competitiveness opportunities and barriers by business executives who are dealing with local and global business situations. Moreover a final discussion of the main findings of the competitiveness analysis have been translated in terms of a SWOT analysis, that has the advantage of being easily readable by the industry itself and by decision makers.

The main result of the study is that the growth in wind capacity installed in Italy has led to the development a new industry composed of multinational subsidiaries and local companies, operating in different areas of the supply chain has developed. The sector has been characterised by high dynamism and by increasing competitiveness, along the all supply chain that has promoted the development of new companies and new business that have had positive return on income and jobs. Positive advanced factor conditions, like physical resources, the high level of renewable energy demand due to the high fossil fuel dependance of Italy, government policies supporting the domestic market have positively influenced competitiveness of the industry. The main weakness of the industry is that it has still a marginal role in technology production, and R\&D activities, which are commonly carried out abroad. However the learning process that has been created has been a stimulus for new turbine and component R\&D activities.

Therefore, actors and decision makers could attempt to further strengthen positive factors and overcome the negative ones in order to increase competitiveness of the national wind industry.

Keywords: Italy, wind energy industry, competitiveness, SWOT analysis. JEL classifications: O13, O32 
L'eolico in Italia: stato del settore e competitività secondo il modello a Diamante di Porter, di Marco Frey, Roberta Squillace

L'energia eolica in Italia è cresciuta a ritmi sostenuti negli ultimi anni, presentandosi come opzione ideale per il raggiungimento di obiettivi di sostenibilità del settore energetico in Italia. Il presente studio si propone pertanto di delineare lo status quo del settore eolico in Italia e delineare i principali fattori di competitività dell'industria, considerando l'intera supply chain e tradurre i principali risultati in termini di SWOT analisi. Il modello teorico utilizzato è dato dal modello del Diamante di Porter, opportunamente modificato, che permette di avere una rappresentazione integrata dei principali fattori che incidono sulla competitività di una industria. Il principale risultato che emerge dallo studio è che il crescente peso dell'eolico come opzione energetica ha favorito la nascita di una industria che ha mostrato segnali di dinamismo. Se inizialmente poche aziende e essenzialmente multinazionali estere o grandi aziende energetiche nazionali operavano nel mercato, ora il settore include nuove aziende di varie dimensioni che operano nei vari settori della supply chain, da operatori di parchi, a produttori di turbine e componenti a fornitori di servizi. Tuttavia la capacità di produzione di tecnologia è ancora marginale. Lo studio, quindi, evidenzia la necessità di rafforzare quei fattori positivi di competitività e affrontare le debolezze che l'industria eolica presenta in Italia, al fine di poterne accrescere la competitività.

Parole chiave: Italia, industria eolica, competitività, analisi SWOT.

I Payments for Ecosystem Services: opportunità di sviluppo nella tutela delle risorse paesaggistico-ambientali, di Stefania Troiano, Francesco Marangon

La protezione del paesaggio è stata per lungo tempo affidata alla Pubblica Amministrazione, che per lo svolgimento di questo compito si è avvalsa degli strumenti vincolistici. Questi ultimi, però, si sono dimostrati incapaci di far fronte alle conseguenze negative derivanti dall'abbandono dei terreni. Questa constatazione ed il declino delle risorse finanziarie stanziate a favore della protezione delle risorse paesaggistico-ambientali hanno favorito l'affermarsi di strumenti alternativi, quali gli strumenti economici per la tutela delle risorse paesaggistico-ambientali, che prevedono un ruolo preponderante degli attori privati.

In base agli studi sulla valutazione monetaria e non monetaria dei beni paesaggistico-ambientali condotti negli ultimi anni, che hanno consentito, da un lato, di individuare le caratteristiche che rendono attraente un paesaggio, e, dall'altro lato, di identificare la disponibilità a pagare per fruire di un servizio paesaggistico-ambientale, l'articolo descrive le possibilità di creazione di un mercato per i servizi derivanti dalla protezione del paesaggio. Viene approfondito, in particolare, il caso dei Payments for Ecosystem Services (PES), strumenti economici utilizzati a favore della conservazione/valorizzazione dei servizi forniti dalle risorse paesaggistico-ambientali. Dopo una sintetica analisi di questa strumentazione, l'articolo si sofferma sulle prospettive di sviluppo in Italia di specifiche categorie di PES, che hanno per oggetto alcune risorse paesaggistico-ambientali preferite dagli utenti.

Parole chiave: Payment for Ecosystem Services, risorse paesaggistico-ambientali, sviluppo sostenibile. 
Payments for Ecosystem Services: Development opportunities from landscape and environmental resources management, by Stefania Troiano, Francesco Marangon

Landscape provides a wide range of benefits to people. There is increasing consensus about the importance of conserving these "ecosystem services". Despite their high practical value ecosystem services provided by landscape - with rare exception - are neither prized by markets nor explicitly protected by the law. In detail, the command and control instruments usually used by government to protect landscape have been demonstrating not to be able to counteract landscape abandonment. Consequently there is increasing pressure to use innovative instruments for promoting, but also financing landscape conservation. Economic theory suggests that some form of contracting between the beneficiaries and the providers could result in an optimal supply of ecosystem services.

In recent years, a number of initiatives around the world have sought to create markets for ecosystem services provided by landscape. National governments and public-private partnerships involving local communities, NGOs, firms and municipalities are among the many actors driving these initiatives. Some markets are dependent on government intervention, while some other are created by entirely private ventures.

Payment for ecosystem services (PES) is a recent instruments innovation attracting attention in both developed and developing countries. It involves voluntary payments for ecosystem services that are conditional on service delivery. They compensate individuals or communities for undertaking actions that increase the provision of ecosystem services. PES schemes rely on payments to induce behavioral change, thus they can be considered part of the group of incentive- or market-based instruments for environmental policy. The analysis of PES is considered one of the most important themes in sustainable environmental research. There is therefore a need to identify and address its pitfalls.

The piece reviews the literature on PES and identifies some key requirements for instrument design. In fact, although simple in appearance, the definition of PES hides many technical complexities.

We argue the opportunity to use this instruments in Italy to conserve landscape. We try to offer a set of lessons about how the context of a PES instruments is likely to interact to produce effectiveness in achieving conservation goals and sustaining landscape health more generally.

We continue by discussing some questions about preconditions necessary to develop PES and by pointing out that quantifying the levels and values of ecosystem services provided by landscape is considered so useful and persuasive but has proven difficult. We point out that establishing PES is a very complex undertaking. In fact, it requires the consideration of scientific but also economic, social, political, institutional, etc. relationships to avoid that possible adverse effects can occur in particular where property rights are insecure. Moreover, we note that PES may need to be complemented with other approaches to address landscape conservation.

The conclusion provides some policy recommendations for the future development of PES initiatives in favour of landscape in Italy, assuming that they should be favoured over the more traditional regulatory and tax-based approaches in far more settings than commonly assumed.

Keywords: Payment for Ecosystem Services, landscape and environmental resources, sustainable development.

JEL classifications: H4, H23, Q57. 
Energia e ambiti materiali connessi: la lettura della Corte costituzionale, di Camilla Buzzacchi

La giurisprudenza della Corte costituzionale in tema di energia sta mettendo in evidenza, a partire dal 2004, un complesso di interessi che sono coinvolti dalle decisioni energetiche, talvolta prevalendo sull'interesse alla sicurezza dell'approvvigionamento energetico, talvolta recedendo rispetto ad esso. Si tratta degli ambiti tutela dell'ambiente, della tutela del paesaggio, della tutela della salute, della tutela della concorrenza, dei livelli essenziali delle prestazioni, della sicurezza: il contributo analizza singolarmente i vari ambiti materiali interessati dalle decisioni di Stato e Regioni in materia di energia, indicando il bilanciamento che di essi è stato effettuato da parte della Corte costituzionale.

Parole chiave: energia, tutela dell'ambiente, tutela del paesaggio, tutela della salute, tutela della concorrenza, livelli essenziali delle prestazioni, sicurezza, Corte costituzionale.

Energy and other areas of interest: The case law of the Constitutional Court, by Camilla Buzzacchi

The case law of the Constitutional Court about energy has been giving evidence since 2004 to a mix of areas of interest affected by decisions concerning energy. These interests sometimes prevail, other times it happens that the needs of energy supply are judged of greater value. The further interests involved in decisions about energy are environment protection, landscape protection, health, competition, essential levels of rights, safety: the essay analyses each single field of interest affected by regional and national provisions, focusing on the balance made by the Court.

Keywords: energy, environment, landscape, health, competition, essential levels of rights, safety, Constitutional Court.

JEL classifications: K21, K30, K32.

\section{Sui costi di generazione dell'energia elettrica da fonte nucleare, di Carlo Mari}

Viene presentata un'analisi dei costi di generazione dell'energia elettrica da fonte nucleare e da fonti fossili (carbone e gas naturale) effettuata sui dati tecnici pubblicati nell'ultimo rapporto IEA-NEA "Projected Costs of Generating Electricity" (Edizione 2010). Lo studio è finalizzato a determinare il "Levelised Cost of Electricity" in un contesto di libero mercato e secondo logiche privatistiche. A fini comparativi e per completare il quadro di riferimento, il lavoro include anche una valutazione dei costi di generazione basata sui dati tecnici ed economici statunitensi riportati in "Update on the Cost of Nuclear Power" (2009) del Massachusetts Institute of Technology. Le valutazioni del MIT sembrano infatti sottostimare i costi di generazione specie se confrontati con i valori riportati nel precedente rapporto "The Future of Nuclear Power" (2003).

I risultati mostrano che in un contesto di politica energetica caratterizzata da incertezza nei programmi di sviluppo e nelle modalità di attuazione, l'energia da fonte nucleare non sembra possedere quei requisiti di competitività economica necessari a pre- 
vederne un utilizzo significativo nel prossimo futuro. Nel lavoro, inoltre, viene sviluppata un'analisi di sensitività rispetto alle grandezze finanziarie più rilevanti, quali il livello di rischiosità percepita dagli investitori e catturata dai valori del costo opportunità del capitale, e il rapporto di indebitamento iniziale, nel tentativo di individuare le principali criticità e l'incidenza dei singoli fattori di rischio che, in un contesto di libero mercato, influenzano la competitività della fonte nucleare. Una sezione dedicata alla valutazione dei costi "sociali" di generazione conclude il lavoro.

Parole chiave: energia nucleare, costo opportunità del capitale.

On the cost of generating electricity from nuclear power, by Carlo Mari

Based on technical data recently published by the IEA-NEA report "Projected Costs of Generating Electricity" (2010), this work provides a theoretical and an empirical cost analysis of generating electricity from nuclear and fossil sources (coal and natural gas). The aim is to determine the "Levelised Cost of Electricity" (LCOE) in a merchant financing context.

To complete the reference framework, we also discuss an empirical analysis of the cost of generating electricity performed on the U.S.A. technical data reported in the MIT study "Update on the Cost of Nuclear Power" (2009). In fact, MIT results seem to underestimate electricity generating costs especially if they are compared with those contained in the previous report "The Future of Nuclear power" (2003).

The obtained results show that in a policy framework characterized by uncertainty on energy development programs, nuclear power does not seem to be competitive with respect to fossil sources even in presence of emission credits. The paper also provides a sensitivity analysis of LCOE with respect to the cost of capital, accounting for the level of risk perceived by investors, and with respect to the initial debt-ratio of the investment, in order to put in evidence the main factors affecting the economic viability of nuclear power in a merchant financing context. A section on the "social" costs of generating electricity concludes the work.

Keywords: nuclear power, levelised cost of electricity.

JEL classifications: L94, G31, Q40, M21. 